\title{
Clear cell HCC mimicking to hepatic adenoma
}

\author{
Ali Kemal Sivrioglu, ${ }^{1}$ Muzaffer Saglam, ${ }^{2}$ Mehmet Incedayi, ${ }^{2}$ Guner Sonmez ${ }^{2}$
}

${ }^{1}$ Department of Radiology, Aksaz Military Hospital, Mugla, Turkey

${ }^{2}$ Department of Radiology, GATA Haydarpasa Teaching Hospital, Istanbul, Turkey

\section{Correspondence to} Dr Mehmet Incedayi, m_incedayi@yahoo.com
To cite: Sivrioglu AK, Saglam M, Incedayi M, et al. BMJ Case Rep Published online: [please include Day Month Year] doi:10.1136/ bcr-2013-008901

\section{DESCRIPTION}

A 60-year-old man was complaining of a postprandial heartburn and of abdominal distention. Physical examination was normal except for nodular, painless hepatomegaly. $\gamma$-Glutamyl transferase (GGT), alanine transferase (ALT) and aspartate transferase (AST) levels were 88 (normal range, 11-66 U/1), 75 (normal level $<40 \mathrm{U} / \mathrm{l}$ ) and $56 \mathrm{U} / 1$ (normal level $<40 \mathrm{U} / \mathrm{l}$ ), respectively. Tumour markers including $\alpha$-fetoprotein $120.7 \mathrm{ng} / \mathrm{ml}$ (normal range $0-7 \mathrm{ng} / \mathrm{ml}$ ) and carcinoembryonic antigen (CEA) $2.2 \mathrm{ng} / \mathrm{ml}$ (normal range $0-5.2 \mathrm{ng} / \mathrm{ml}$ ). Viral serological studies were HBsAg $(+)$, HBsAb (-), HBV DNA (+), anti-Delta (-) and

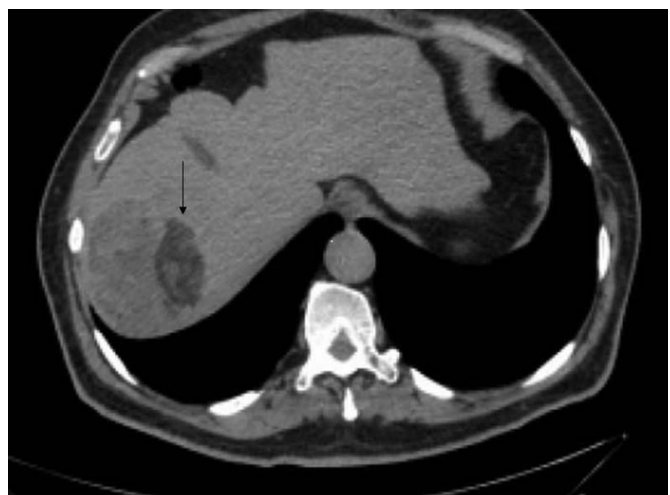

Figure 1 Axial non-contrast CT image showing heterogeneously hypodense mass lesions with a macroscopic fatty change.

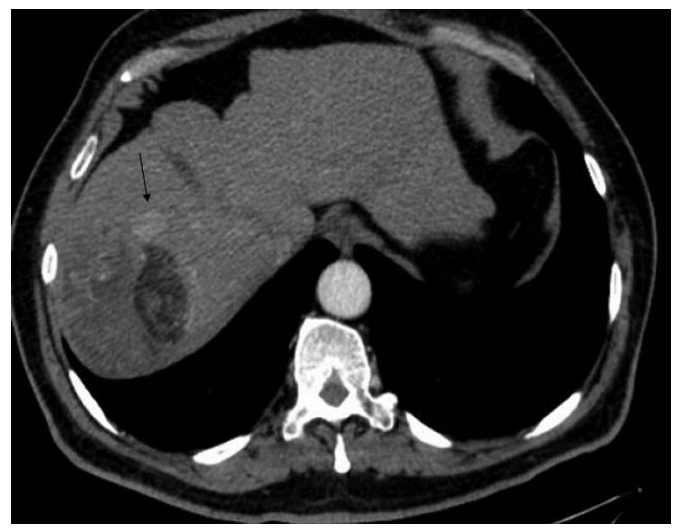

Figure 2 On axial contrast-enhanced CT image, lesions showing enhancement heterogeneously on arterial phase.
anti-HCV (-). Other blood test results were within normal limits.

Posteroanterior chest X-ray was normal. Ultrasonographic examination of the liver showed diffuse increased echogenicity and coarse echotexture. A large mixed echogenic mass was seen in the right hepatic lobe. CT showed heterogeneously hypodense mass lesions with fatty change on noncontrast scans and enhance heterogeneously on both arterial phase and venous phase postcontrast scans (figures 1 and 2). Following tru-cut biopsy, it was ascertained to be a clear cell hepatocellular carcinoma (HCC).

Clear cell HCC may include large fatty areas and this is often misdiagnosed to be an adenoma. Clear cell HCC cannot be differentiated with imaging methods from hepatic adenoma including macroscopic fatty tissue. ${ }^{12}$ However if the patient is man and has a chronic liver disease, the diagnosis will be strongly clear cell HCC instead of adenoma. Tru-cut biopsy is the best choice in diagnosis. Clear cell HCC is characterised by high female prevalence (the male-to-female ratio is $2.3: 1$, lower than the 6.9:1 of non-clear cell HCC), high rate of association with liver cirrhosis and has no significant difference in prognosis compared with non-clear cell HCC. ${ }^{3}$

\section{Learning points}

- Clear cell hepatocellular carcinoma (HCC) may include large fatty areas.

- Clear cell HCC cannot be differentiated with imaging methods from hepatic adenoma including macroscopic fatty tissue.

Competing interests None.

Patient consent Obtained.

Provenance and peer review Not commissioned; externally peer reviewed.

\section{REFERENCES}

1 Chung YE, Park M, Park YN, et al. Hepatocellular carcinoma variants: radiologic-pathologic correlation. AJR 2009;193:W7-13.

2 Prasad SR, Wang $\mathrm{H}$, Rosas $\mathrm{H}$, et al. Fat-containing lesions of the liver: radiologic-pathologic correlation. Radiographics 2005; 25:321-31.

3 Yang SH, Watanabe J, Nakashima 0, et al. Clinicopathologic study on clear cell hepatocellular carcinoma. Pathol Int 1996;46:503-9. 


\section{Images in...}

Copyright 2013 BMJ Publishing Group. All rights reserved. For permission to reuse any of this content visit http://group.bmj.com/group/rights-licensing/permissions.

BMJ Case Report Fellows may re-use this article for personal use and teaching without any further permission.

Become a Fellow of BMJ Case Reports today and you can:

- Submit as many cases as you like

- Enjoy fast sympathetic peer review and rapid publication of accepted articles

- Access all the published articles

- Re-use any of the published material for personal use and teaching without further permission

For information on Institutional Fellowships contact consortiasales@bmjgroup.com

Visit casereports.bmj.com for more articles like this and to become a Fellow 